\title{
Reported theory use in walking interventions: a literature review and research agenda
}

\author{
ABSTRACT \\ There is mixed evidence with some suggesting walking can be increased up to the recommended level through interventions based \\ on behaviour change models and others showing partial or no effects (Arbour and Ginis, 2009; Merom et al., 2009; Ornes and \\ Ransdell, 2010). Taken together, prior studies suggest that ongoing research attention is warranted. Walking behaviour change \\ intervention studies were searched using key search words “walking promotion” and "pedometer” in the PubMed database. Initially, \\ 87 articles were found and 25 walking behaviour change interventions were reviewed to focus attention on reported theory use. \\ Results of the review suggest that interventions that are theoretically underpinned may be no more effective than their counterparts. \\ The Transtheoretical Model (TTM) and Social Cognitive Models were most frequently reported with positive effects noted for TTM \\ use. The review also indicates that using single theory may be better than using multiple theories in a single intervention.
}

\section{KEY WORDS}

Walking, Behaviour change, Effectiveness, Review, Intervention, Theory

\section{INTRODUCTION}

Chronic diseases are the leading cause of death among adults in the world (World Health Organization, 2011), mostly in middleand high-income countries (World Health Organization, 2011). Of further concern, the burden of chronic disease is rapidly rising in low- and middle-income countries (Alwan et al., 2010). While clinical interventions with medicine and surgery can cure chronic diseases, these are expensive, have side effects, and most importantly clinical interventions are not equally accessible across socioeconomic groups (Schroeder, 2007). Interventions focusing on changing peoples' health behaviour such as the recommended level of walking, 30 minutes per day, undertaking physical activity 5 days per week (Pate et al., 1995) or 10,000 steps/day (TudorLocke et al., 2011) have been found to be successful in reducing morbidities and mortality related to chronic diseases including physical and mental illness (Brisson and Tudor-Locke, 2004; Galper et al., 2006) and health care costs (Lee and Buchner, 2008). Statistics indicate that people do not walk regularly up to recommended levels. For example, in the USA the national prevalence of insufficient physical activity is on average $51.4 \pm 5.6 \%$ (Brock et al., 2009). This is consistent with Australia, where current evidence suggests that people do not walk up to recommended levels (VicHealth, 2012). Moreover, walking rates appear to be decreasing over time in Australia. Adult Australians walked on average 7.0 hours in 1989-90 and 5.5 hours in 2007-08 in the two weeks prior to the survey (Australian Institute of Health and Welfare, 2012). It is, therefore, important to change people's walking behaviour to reduce the risk of chronic diseases.

Behavioural interventions can lower health system costs (Marteau et al., 2006). Millions of dollars are spent each year by local, state and Federal governments in the hope that behavioural change can be effected to reduce chronic disease. Public health care spending is projected to rise further. Forecasts indicate, for instance, that health and social care costs will rise from 5.7\% in 2005 to between 7.7\% and 9.6\% of GDP by 2050 (Appleby, 2013). Expenditure may be poorly directed, given research indicating traditional 
approaches have not worked (Laska et al., 2012; Fildes et al., 2015). Evidence indicates that expert-led, diet and education focused (Jeffrey, 2001) interventions that dominate current obesity intervention practice do not work. Of note, low intervention uptake rates have been prominent (Fildes et al., 2015).

Theory based behavioural interventions have been identified as more effective in changing health behaviour than non-theory based interventions (Marteau et al., 2006; Glanz and Bishop, 2010; Chao et al., 2013) suggesting there is an ongoing need to review application of different behaviour change theories to understand which theoretical frameworks have previously been used to deliver increases in walking. There is evidence indicating that if theory is used it is not clearly reported (Davis et al., 2015). Establishing an evidence base to guide future walking behaviour change efforts ensures that best practice programs achieving behavioural change are funded. This paper aims to examine reported theory use in walking behaviour change interventions reported since 2007.

\section{METHODS}

Walking behaviour change interventions were searched with the key words "walking promotion” and "pedometer” through PubMed, a web-based gold standard database for searching control trials (Robinson and Dickersin, 2002). The search was limited to peer-reviewed academic journal articles published since 2007. There are available reviews of evidence on the built environment correlates of walking from 2002 to 2006 (Saelens and Handy, 2008). Articles based on qualitative research methods, nonintervention, physical activity other than walking, children as participants and articles not in English were excluded from the review. The current review was focused on empirical interventions which aimed to increase walking among adults. All search results were downloaded to EndNote. Duplicate search results were identified and removed. Titles and abstracts of the remaining articles were reviewed to locate articles that met the study aim, namely they evaluated the efficacy of interventions. Forward searching was conducted using both the author and intervention name within Google Scholar and the university library database to look for additional information on the interventions. Figure 1 illustrates the search process used to identify the 25 articles. Full text was downloaded. All the relevant articles were studied to address the research problems and exclusion criteria were applied (see Figure 1). Data related to authors, year of publication, research design, participants' age in years, reported theory and construct use in the intervention, intervention components, intervention period, measures of both dependent and independent variables and walking as the outcomes of all the interventions were extracted by reading the full article. Extracted data were analysed to identify the effectiveness of the reported behaviour change theories used in the interventions. Extractions were conducted by the lead author and the co-author independently reviewed the effectiveness classifications with 100\% agreement attained. Effectiveness of the interventions was measured in terms of the changes in walking behaviour. Not effective, partially effective and fully effective were categorized if walking behaviour did not change due to the intervention, if there was within-group change but no between-group significant change, and if there were both within- and between-group significant changes respectively. Fisher’s exact test was used to examine the group differences. 


\section{RESULTS AND DISCUSSION}

Initially, 87 articles were found following the search strategy described in the method section above. After reviewing the titles and abstracts of all 87 articles and applying exclusion criteria (see Figure 1), 25 studies, which measured walking behaviour, were identified as relevant to the evaluation of walking behaviour change interventions. A summary of the interventions that were reviewed is presented in Table 1 .

Effectiveness of the interventions

Table 1 reveals that the majority $(68 \%, n=17)$ of the interventions were able to successfully change walking behaviour by increasing the number of steps and time spent walking per day or week (Vallance et al., 2007; De Cocker et al., 2008; Faghri et al., 2008; Hemmingsson et al., 2008; Arbour and Ginis, 2009; Merom et al., 2009; Yates et al., 2009; Darker et al., 2010; Furber et al., 2010; De Greef et al., 2011; Samuels et al., 2011). For example, the Darker (2010) study resulted in a large increase in the number of minutes spent walking while in the De Greef et al. (2011) study walking increased by 2,744 steps per day in the intervention group. While positive walking outcomes were observed for some groups of the population (De Greef et al., 2011) there were groups where interventions were ineffective. For example, inactive and insufficiently active participants increased their walking while active participants did not (Estabrooks et al., 2008; Puig-Ribera et al., 2008). Finally, some interventions were unsuccessful. For example, no significant difference between intervention and control groups was observed in the Merom et al. (2007) study.

Effectiveness of the theories

Extracted data from the articles were analysed to examine reported theory use, observed constructs, and behavioural outcomes according to three categories - not effective, partially effective and fully effective. Cross-tab and Fisher's exact test were used to examine the group differences.

Table 2 indicates data patterns that are suggestive of differences. However, the differences were not statistically significant. Table 2 shows that among the 25 interventions $56 \%$ of the studies reported use of a behaviour change theory which indicates the insufficient use of theories in developing health promotion interventions (Van den Broucke, 2012 and 2014). Among the 14 studies which used behaviour change theory and assessed its effectiveness, $71.4 \%$ were fully effective and 28.6\% were partially effective in changing walking behaviour. Among the 14 interventions which effectively changed walking behaviour Furber et al. (2010) reported the maintenance of changed walking behaviour at 6 month follow-up and Darker et al. (2010) reported sustained behaviour change at 6 week follow-up. Among the 11 interventions which did not report theory use $63.6 \%$ were fully effective in delivering behaviour change, $18.2 \%$ were partially effective and $18.2 \%$ were not effective in changing walking behaviour. The results presented in table 2 indicate that theory-based interventions are not statistically significantly different from non-theory based interventions in terms of the proportion delivering positive behavioural change outcome. However, it is important to note that patterns are discernible. A larger sample of studies is needed to permit statistical significance to be established.

The current review of contemporary studies (since 2007) indicates a range of theories that have been employed successfully to increase walking behaviour. The following section outlines the reported behaviour change theories that have been used to increase 
walking behaviour. There were four interventions (Perry et al., 2007; Estabrooks et al., 2008; Ryder et al., 2009; Strath et al., 2011) which reported multiple theory usage. Therefore, a total of 18 different theories are reported across 14 interventions.

Social Cognitive Theory, Transtheoretical Model, Ecological Model, Diffusion Theory, Theory of Planned Behaviour, Implementation Intentions and Self-regulatory Theory were reported in reviewed studies (see Table 2). Social Cognitive Theory and the Transtheoretical Model were the most frequently reported theories. The effectiveness of walking behaviour change interventions will now be detailed by theory.

Table 2 also illustrates that $71.4 \%$ of the interventions reported using single theory of which $80 \%$ were fully effective and $20 \%$ were partially effective in changing walking behaviour.

Social Cognitive Theory

Social Cognitive Theory (Bandura, 1997), the most commonly used health behaviour theory, is categorised as a theory of interpersonal health behaviour which describes how individuals (cognition and other personal factors) and their environments interact and influence each other resulting in behaviour change (Glanz, Rimer and Viswanath, 2008). Social Cognitive Theory is considered as a multi-construct process model with outcomes typically centred on increasing self-efficacy or reducing barriers to the desired behaviour (Aunger and Curtis, 2007). In the current review the Social Cognitive theory was the most frequently used theory (32\%). It was used alone in $16 \%$ of the interventions.

The Social Cognitive Theory was found in some cases to be either fully effective in changing walking behaviour (Perry et al., 2007; De Cocker et al., 2008; Estabrooks et al., 2008; Furber et al., 2010) or partially effective (Merom et al., 2007; Merom et al., 2009; Ryder et al., 2009; Strath et al., 2011). Fifty-percent of the interventions (4/8) based on the Social Cognitive Theory reported increases in walking behaviour while 50\% reported mixed effects. Results indicate that the full set of the constructs of the Social Cognitive Theory were not used in one intervention. Facilitation was implemented in different ways including a 10,000 steps/day recommendation (De Cocker et al., 2008), provision of pedometers (Furber et al., 2010; Merom et al., 2007; Merom et al., 2009) and telephone support (Furber, 2010). The self-regulation construct was evident with examples identified including walking goalsetting (De Cocker et al., 2008), step calendars (Furber et al., 2010), goal setting sessions (Furber et al., 2010) and weekly diaries (Merom et al., 2007; Merom et al., 2009). The behavioural capability construct was evident with examples identified including providing information about the importance of physical activity (De Cocker et al., 2008), tips on how to increase physical activity (De Cocker et al., 2008), behavioural counselling (Furber et al., 2010), self-help booklets (Merom et al., 2007; Merom et al., 2009), and tips through mail and telephone (Merom et al., 2007, Merom et al., 2009). Core Social Cognitive Theory constructs such as reciprocal determinism and self-efficacy were not evident in walking interventions identified in this review. Using longer intervention-periods (Merom et al., 2007), overcoming environmental barriers for walking (Merom et al., 2009), measuring walking by step-count, addressing the barriers of pedometer use, using larger and more diverse samples (Ryder et al., 2009) and using different intervention delivery methods (Strath et al., 2011) and using more constructs were recommended by the authors to improve interventions using Social Cognitive Theory. 


\section{Transtheoretical Model}

Transtheoretical Model (Prochaska and DiClemente, 1983), a process model, offers an explanation of an individual’s health behaviour over time (Glanz, Rimer and Viswanath, 2008). Constructs of the Transtheoretical Model are clustered as (a) Stages of Change, (b) Processes of Change, (c) Decisional Balance, and (d) Self-Efficacy.

In our review, the Transtheoretical Model was the second most commonly reported (20\%) theory in walking behaviour change interventions. It was used alone in $12 \%$ of interventions. Precontemplation, contemplation, preparation and action stages were reported in different interventions. All of the stages were not reported in one single intervention. For example, Hemmingsson et al. (2008) raised consciousness about walking in the precontemplation stage using a walking promotion booklet and Faghri et al. (2008) used motivational messages through email and website targeting the contemplation stage. Kolt et al. (2010) prepared participants for walking providing primary care physical activity prescription as an action plan and Faghri et al. (2008) and Hemmingsson et al. (2008) distributed pedometers among intervention participants to walk. The maintenance stage was not reported in any intervention. Moreover, no other constructs were reported in any of the interventions designed based on the Transtheoretical Model. The Transtheoretical Model was found to be fully effective when used alone (Faghri et al., 2008; Hemmingsson et al., 2008; Kolt et al., 2012).

Implementation Intention

The implementation Intention theory (Gollwitzer, 1999) is categorised as a single construct theory (Aunger and Curtis, 2007) whose behavioural change objective is to induce people to form intentions that promote desired behaviour. Implementation Intention theory was found to be effective in changing walking behaviour in the single cases identified in the literature review (Arbour and Ginis, 2009). Advice to achieve a goal of 3500 additional pedometer steps 3 days/week and verbal encouragement were used to develop intentions to walk. Literature review and meta-analysis on the Implementation Intention support the effectiveness of this theory to change walking behaviour (Gollwitzer and Sheeran, 2006; Webb and Sheeran, 2006). However, more walking behaviour change intervention studies should be undertaken using the Implementation Intention theory to ascertain whether these results can be replicated and extended in different settings and target populations.

\section{Theory of Planned Behaviour}

The Theory of Planned Behaviour (Ajzen and Fishbein, 1973) is categorised as an intrapersonal (Rimer and Glanz, 2005) and multiconstruct (Aunger and Curtis, 2007) theory which examines the relations between an individual's beliefs, attitudes, intentions, behaviour, and perceived control over that behaviour (Rimer and Glanz, 2005).

Theory of Planned Behaviour was found to be effective in changing walking behaviour in the single cases (Darker et al., 2010) identified in the literature review. Motivational interviewing was used to develop intention and positive attitude to walking. Goal setting, action planning and coping planning strategies were used to build perceived behavioural control. More walking behaviour change intervention studies should be undertaken using the Theory of Planned Behaviour Extended to ascertain whether these results can be replicated and extended in different settings and target populations. 
Self-regulation Theory

Self-regulation Theory (Leventhal, Zimmerman, and Gutmann, 1984) emphasises the role of goal setting, planning and selfmonitoring in behaviour change (Kanfer, 1986). It was found to be effective in changing walking behaviour in the single cases identified in the literature review (Sugden et al., 2008). Motivational techniques, goal setting techniques, barrier identification and consequent techniques, action plans, coping plans, pedometer, daily activity diary and telephone contact were used in interventions reporting Self-regulation Theory.

Next, the effectiveness of reported combined use of theories in changing walking behaviour was considered. Interventions reported using multiple theories (28.6\%) of which $50 \%$ were fully effective and $50 \%$ were partially effective in changing walking behaviour.

Social Cognitive Theory and Transtheoretical Model

Of the interventions (8\%) reporting combined use of the Social Cognitive Theory and the Transtheoretical Model, $50 \%$ were fully effective (Perry et al., 2007) and 50\% were partially effective (Strath et al., 2011). Motivational interviews, booster telephone calls, individualized and realistic goals, progress monitoring, individualised exercise prescription, weekly group walk, encouragement, positive reinforcement, weekly discussion, group T-shirt, encouragement to telephone each other, individualised and private advice session and reinforcement telephone call (Perry et al., 2007); educational physical activity literature (educational materials on the benefits of physical activity, how to make physical activity as part of daily life), pedometer, generic goal to increase physical activity up to 10000 steps/day, individualised motivational literature (perceived barriers to physical activity and effective strategies to overcome it) and telephone contact to discuss barriers and strategies to overcome barriers identified (Strath et al., 2011) were used as intervention strategies in studies reporting use of both Social Cognitive Theory and the Transtheoretical Model.

\section{Social Cognitive Theory and Diffusion Theory}

Since the Social Cognitive Theory has been described separately earlier in this paper, only the Diffusion of Innovations theory will be described in this section. Diffusion of Innovations theory is categorised as a group, organisation and community behaviour change theory which focuses on how new ideas, products, programs, and social practices spread within a society or from one society to another (Glanz, Rimer and Viswanath, 2008). Diffusion is defined as a process by which an innovation is communicated through certain channels over time among the members of a social system (Rogers, 2003; Aunger and Curtis, 2007). Diffusion of Innovations theory (Rogers, 1995) is also categorised as a segmentation-based behaviour change approach whose behaviour change objective is to get early adopters to adopt the target behaviour and assist in diffusing the behaviour through the population (Aunger and Curtis, 2007)

Social Cognitive Theory was used in combination with Diffusion Theory (4.0\%) in an intervention with effective results recorded (Estabrooks et al., 2008). Newsletters included fun messages; activities to increase physical activity, weekly team mileage update and flexibility to select team were used as intervention strategies. It seems that appropriate communication channels were used to diffuse the intervention among the Kansas community. However, adidtional reseacrh is recommended to establish efficacy of dual theory use for the the Social Cognitive Theory and Diffusion Theory in changing walking behaviour. 
Social Cognitive Theory and Social Ecological Model

Social Ecological Model (McLeroy, Bibeau, Steckler, and Glanz, 1988) is categorised as a multi-level approach (Aunger and Curtis, 2007) which proposes that individual, interpersonal, community, organisational, and societal factors should be taken into account when planning and implementing health promotion interventions, since they have influences on behavioural choices (Israel, Checkwoay, Schulz and Zimmerman, 1994; McLeroy, Bibeau, Steckler, and Glanz, 1988). The Social Ecological Model extends beyond individuals and encompasses changes to the physical, built or socio-political environment in a way that promotes desirable behaviour (Aunger and Curtis, 2007).

Social Cognitive Theory was used in combination with the Social Ecological Model (4.0\%) in an intervention with partially effective results recorded (Ryder et al., 2009). Pedometer, walking recommendations, maps of local trails, and advertisements were used to target individuals. However, it is not clear if any changes to the physical, built or socio-political environment that would bring change in walking behaviour were made. Rather the intervention strategies employed incentive motivation and facilitation concepts of Social Cognitive Theory.

Taken together, results from the literature review indicate that using a single theory to guide the development of an intervention may be better than using multiple theories in a single walking intervention. In the current study positive outcomes (walking behaviour change) were more likely when a single theory was reported in contrast to multiple theory use. Further, results indicate the Transtheoretical Model has previously been used to change walking behaviour and single cases of positive effects from reported use of Theory of Planned Behaviour and Implementation Intention were noted suggesting these offer guiding frameworks for behavioural change intervention planners.

Psycho-social constructs co-occur between theories limiting inference about guiding theoretical frameworks in the absence of clear theory reporting. Observable constructs are reported in Table 1 providing an initial summative overview of construct use in behavioural change interventions. In the current study a variety of psycho-social constructs were observed. Social support, empowerment, team building, motivation, monitoring and feedback, planning and goal setting, memory and education were observed in interventions with positive outcomes. Taken together, the results in the current study indicate more research is needed before definitive conclusions can be drawn about the need to use theory to achieve behavioural change given a lack of statistically significant findings between studies reporting theory use and studies that did not report theory use.

The current review has limitations. First, it was not a systematic review, nor a meta-analysis. Second, the review was limited to English papers. Third, articles were searched by two keywords in one database and the review was focused on papers published from 2007 onwards. A systematic literature review that extends into additional databases and extends the search terms to provide comprehensive coverage of articles is recommended to extend understanding further. Further, reviews of papers reported in languages other than language are recommended to extend understanding. The current study was limited to reported theory use, which may limit understanding given theory may underpin study design but not be reported. Inevitably, studies considered in this review may have utilised theory but not have explicitly reported the theoretical framework. Given that some constructs overlap between theories, classification of observable constructs into a theoretical framework cannot deliver reliable insights. A narrative 
technique was used to report findings in the current study given that meta-analysis was not possible due to study heterogeneity, including variation of data analysis approaches (i.e. both qualitative and quantitative) and the absence of a common statistical measure including reported effect sizes for interventions. Given that study heterogeneity, which included different methodological approaches and the absence of a common statistical measure prevented meta-analysis from being undertaken future research is recommended. First, the use of consistent outcome measures and analytical approaches is needed which in turn can be used to deliver meta-analytical studies. The use of meta-analysis would permit an understanding of the factors leading to intervention effectiveness thus better informing future practice. Strategies of behaviour modification (eg. counselling) warrant future research attention. Experimental design that controls for exposures to a behaviour modification strategy would extend understanding of the relative role of theory application vis-à-vis behavioural modification strategies such as counselling. Theoretical insights are limited in the current study given the majority of studies do not offer full theory reporting. In the absence of full theoretical reporting it is not possible to investigate effects at a deeper level. Moving forward future research needs to report theory clearly. Theory coding schemes such as those provided by Michie and Prestwich (2010) deliver a detailed structure that can be used to guide theory reporting. For example, Michie and Prestwich (2010) state that at least one, but not all, of the theory relevant constructs/predictors should be explicitly linked to at least one intervention technique in one criteria. No examples of theory development were observed in the current review indicating that an opportunity exists to expand theoretical frameworks. The Michie and Prestwich (2010) framework offers theory building structure that can be used to guide theoretical development reporting. Key psycho-social constructs that were linked to positive outcomes in this study include social support, empowerment, team building, motivation, monitoring and feedback, planning and goal setting, memory and education. Together, these factors should be examined in future research studies involving replication to develop a theory of walking behaviour change. Explicit links permit meta-analytic assessment that can be used to investigate effects at a deeper level delivering evidence to guide future practice. Moving forward researchers must clearly report theory use and in turn deliver clear elucidation of theory (and constructs) in intervention planning, implementation and evaluation. Clear theory reporting can in turn be used by researchers in reviews to extend our understanding of which theoretical perspectives can be applied to increase walking.

\section{CONCLUSION}

Theory use was reported in some walking behaviour change interventions reported in the peer reviewed literature post 2007. Statistical analysis indicates that interventions that are theoretically underpinned may be no more effective than their counterparts and close examination of theory reporting identified a failure to include all theoretical constructs suggesting only partial theory use was observed. Among the theories, Transtheoretical Model and Social Cognitive Models were used predominantly in walking behaviour change interventions. Elucidation of theory using guiding frameworks such as those outlined by Michie and Prestwich (2010) are recommended to advance understanding of theories role in delivering behavioural change. Additionally, consideration of new theories is recommended.

\section{COMPETING INTEREST}

The authors declare that they have no competing interests. 


\section{AUTHORS’ CONTRIBUTIONS}

MAK developed the concept, designed the study, searched articles, extracted data, synthesised data and led the drafting of the manuscript. SRT designed the analysis plan, interpreted data, and revised the manuscript critically. All authors read and approved the final manuscript. 


\section{REFERENCES}

Ajzen, I., and Fishbein, M. (1973). Attitudinal and normative variables as predictors of specific behaviors. Journal of personality and Social Psychology, 27(1), 41-57.

Alwan, A., Maclean, D. R., Riley, L. M., d'Espaignet, E. T., Mathers, C. D., Stevens, G. A. and et al. (2010) Monitoring and surveillance of chronic non-communicable diseases: progress and capacity in high-burden countries. Lancet, 376(9755), 1861-1868.

Appleby, J. (2013) Spending on health and social care over the next 50 years. Why think long term, 10.

Arbour, K. P. and Ginis, K. A. M. (2009) A randomised controlled trial of the effects of implementation intentions on women's walking behaviour. Psychology \& Health, 24(1), 49-65.

Aunger, R. and Curtis, V. (2007) A Meta-Model of Behavior Change: Review, Critical Analysis and Future Directions: LSHTM/Hygiene Centre for Unilever PLC.

Australian Institute of Health and Welfare. (2012). Risk factor trends: age patterns in key health risks over time. Canberra: AIHW.

Bandura, A. (1997). Self-efficacy: The exercise of control. Macmillan.

Brisson, T. and Tudor-Locke, C. (2004) The Health Benefits of Physical Activity and the Role of Step Counters. Canadian Journal of Dietetic Practice and Research, 65(1), 26A.

Brock, D. W., Thomas, O., Cowan, C. D., Allison, D. B., Gaesser, G. A. and Hunter, G. R. (2009) Association between insufficiently physically active and the prevalence of obesity in the United States. Journal of Physical Activity \& Health, 6(1), $1-5$.

Chao, Ying-Yu, Scherer, Yvonne K., Wu, Yow-Wu, Lucke, Kathleen T. and Montgomery, Carolyn A. (2013) The feasibility of an intervention combining self-efficacy theory and Wii Fit exergames in assisted living residents: A pilot study. Geriatric Nursing, 34(5), 377-382. doi: http://dx.doi.org/10.1016/j.gerinurse.2013.05.006

Darker, C. D., French, D. P., Eves, F. F. and Sniehotta, F. F. (2010) An intervention to promote walking amongst the general population based on an 'extended' theory of planned behaviour: a waiting list randomised controlled trial. Psychology \& Health, 25(1), 71-88.

Davis, R., Campbell, R., Hildon, Z., Hobbs, L., and Michie, S. (2015). Theories of behaviour and behaviour change across the social and behavioural sciences: a scoping review. Health psychology review, 9(3), 323-344.

De Cocker, K. A., De Bourdeaudhuij, I. M. and Cardon, G. M. (2008) The effect of pedometer use in combination with cognitive and behavioral support materials to promote physical activity. Patient Education and Counseling, 70(2), 209-214. 
De Greef, K. P., Deforche, B. I., Ruige, J. B., Bouckaert, J. J., Tudor-Locke, C. E., Kaufman, J. M. and et al. (2011) The effects of a pedometer-based behavioral modification program with telephone support on physical activity and sedentary behavior in type 2 diabetes patients. Patient Education and Counseling, 84(2), 275-279.

Estabrooks, P. A., Bradshaw, M., Dzewaltowski, D. A. and Smith-Ray, R. L. (2008) Determining the impact of Walk Kansas: applying a team-building approach to community physical activity promotion. Annals of Behavioral Medicine, 36(1), 112 .

Faghri, P. D., Omokaro, C., Parker, C., Nichols, E., Gustavesen, S. and Blozie, E. (2008) E-technology and pedometer walking program to increase physical activity at work. Journal of Primary Prevention, 29(1), 73-91.

Fildes, A., Charlton, J., Rudisill, C., Littlejohns, P., Prevost, A. T. and Gulliford, M. C. (2015) Probability of an obese person attaining normal body weight: cohort study using electronic health records. American journal of public health, 105(9), e54-e59.

Furber, S., Butler, L., Phongsavan, P., Mark, A. and Bauman, A. (2010) Randomised controlled trial of a pedometer-based telephone intervention to increase physical activity among cardiac patients not attending cardiac rehabilitation. Patient Education and Counseling, 80(2), 212-218.

Galper, D. I., Trivedi, M. H., Barlow, C. E., Dunn, A. L. and Kampert, J. B. (2006) Inverse association between physical inactivity and mental health in men and women. Medicine and Science in Sports Exercise, 38(1), 173-178.

Glanz, K. and Bishop, D. B. (2010) The role of behavioral science theory in development and implementation of public health interventions. Annual review of public health, 31, 399-418.

Glanz, K., Rimer, B. K. and Viswanath, K. (Eds.). (2008) Health behavior and health education: theory, research, and practice. San Francisco: Jossey-Bass.

Gollwitzer, P. M. (1999). Implementation intentions: Strong effects of simple plans. American psychologist, 54(7), 493-503.

Gollwitzer, P. M. and Sheeran, P. (2006). Implementation intentions and goal achievement: A meta-analysis of effects and processes. Advances in experimental social psychology, 38, 69-119.

Hemmingsson, E., Hellenius, M. L., Ekelund, U., Bergstrom, J. and Rossner, S. (2008) Impact of social support intensity on walking in the severely obese: a randomized clinical trial. Obesity (Silver Spring), 16(6), 1308-1313.

Israel, B. A., Checkoway, B., Schulz, A. and Zimmerman, M. (1994). Health Education and Community Empowerment: Conceptualizing and Measuring Perceptions of Individual, Organizational and Community Control. Health Education Quarterly, 21(2), 149-170.

Jeffery, R. W. (2001) Public health strategies for obesity treatment and prevention. American journal of health behavior, 25(3), 252259. 
Kanfer, F. H. (1986). Implications of a self-regulation model of therapy for treatment of addictive behaviors. In Treating addictive behaviors (pp. 29-47). Springer, US.

Kolt, G. S., Schofield, G. M., Kerse, N., Garrett, N., Ashton, T. and Patel, A. (2012) Healthy Steps trial: pedometer-based advice and physical activity for low-active older adults. Annals of Family Medicine, 10(3), $206-212$.

Laska, M. N., Pelletier, J. E., Larson, N. I. and Story, M. (2012) Interventions for weight gain prevention during the transition to young adulthood: a review of the literature. Journal of Adolescent Health, 50(4), 324-333.

Lee, I. M. and Buchner, D. M. (2008) The importance of walking to public health. Medicine and Science in Sports Exercise, 40(7 Suppl), S512-S518.

Leventhal, H., Zimmerman, R. and Gutmann, M. (1984). Compliance: A Self-Regulation Perspective. In D. Gentry (ed.), Handbook of Behavioral Medicine. New York: Guilford Press.

Marteau, T., Dieppe, P., Foy, R., Kinmonth, A.-L. and Schneiderman, N. (2006) Behavioural medicine: changing our behaviour: A growing body of evidence shows how to make behavioural interventions effective. British Medical Journal, 332, 437438.

McLeroy K. R., Bibeau D., Steckler A. and Glanz K. (1988). An ecological perspective on health promotion programs. Health Education Quarterly, 15,351-377.

Merom, D., Rissel, C., Phongsavan, P., Smith, B. J., Van Kemenade, C., Brown, W. J. and et al. (2007) Promoting walking with pedometers in the community: the step-by-step trial. American Journal of Preventive Medicine, 32(4), 290-297.

Merom, D., Bauman, A., Phongsavan, P., Cerin, E., Kassis, M., Brown, W. and et al. (2009) Can a motivational intervention overcome an unsupportive environment for walking--findings from the Step-by-Step Study. Annals of Behavioral Medicine, 38(2), 137-146.

Michie, S. and Prestwich, A. (2010) Are interventions theory-based? Development of a theory coding scheme. Health

Psychology, 29(1), 1-8.

Ornes, L. L. and Ransdell, L. B. (2010) A pilot study examining exercise self-efficacy as a mediator for walking behavior in college-age women. Perceptual and Motor Skills, 110(3 Pt 2), 1098-1104.

Pate, R. R., Pratt, M., Blair, S. N., Haskell, W. L., Macera, C. A., Bouchard, C. and et al. (1995) Physical activity and public health. A recommendation from the Centers for Disease Control and Prevention and the American College of Sports Medicine. The Journal of the American Medical Association, 273(5), 402-407.

Perry, C. K., Rosenfeld, A. G., Bennett, J. A. and Potempa, K. (2007) Heart-to-Heart: promoting walking in rural women through motivational interviewing and group support. The Journal of Cardiovascular Nursing, 22(4), 304-312. 
Prochaska, J. and Diclemente, C. (1983). Stages and procesess of self-change of smoking: toward an integrative model of change, $J$ Consult Clin Psichol. 51, 390-5.

Puig-Ribera, A., McKenna, J., Gilson, N. and Brown, W. J. (2008) Change in work day step counts, wellbeing and job performance in Catalan university employees: a randomised controlled trial. Promotion \& Education, 15(4), 11-16.

Rogers, E. (1995). Diffusion of Innovations. 4th ed. New York, NY: The Free Press.

Rogers, E. M. (2003). Diffusion of Innovations. (5th ed.) New York: Free Press.

Robinson, K. A. and Dickersin, K. (2002) Development of a highly sensitive search strategy for the retrieval of reports of controlled trials using PubMed. International journal of epidemiology, 31(1), 150-153.

Rimer, B. K. and Glanz, K. (2005). Theory at a glance: a guide for health promotion practice. US Dept. of Health and Human Services, Public Health Service, National Institutes of Health, National Cancer Institute.

Ryder, H. H., Faloon, K. J., Levesque, L. and McDonald, D. (2009) Partnering with libraries to promote walking among community-dwelling adults: a Kingston gets active pilot pedometer-lending project. Health Promotion Practice, 10(4), 588-596.

Saelens, B. E. and Handy, S. L. (2008) Built environment correlates of walking: a review. Medicine \& Science in Sports \& Exercise, 40(7 Suppl), S550-566.

Samuels, T. Y., Raedeke, T. D., Mahar, M. T., Karvinen, K. H. and DuBose, K. D. (2011) A randomized controlled trial of continuous activity, short bouts, and a 10,000 step guideline in inactive adults. Preventive Medicine, 52(2), 120-125.

Schroeder, S. A. (2007) Shattuck Lecture. We can do better--improving the health of the American people. The New England journal of medicine, 357(12), 1221-1228.

Strath, S. J., Swartz, A. M., Parker, S. J., Miller, N. E., Grimm, E. K. and Cashin, S. E. (2011) A pilot randomized controlled trial evaluating motivationally matched pedometer feedback to increase physical activity behavior in older adults. Journal of Physical Activity \& Health, 8 Suppl 2, S267-274.

Sugden, J. A., Sniehotta, F. F., Donnan, P. T., Boyle, P., Johnston, D. W. and McMurdo, M. E. (2008) The feasibility of using pedometers and brief advice to increase activity in sedentary older women--a pilot study. BMC Health Services Research 8, 169.

Tudor-Locke, C., Mutrie, N., Oppert, J.-M., Rowe, D. A., Schmidt, M. D., Schofield, G. M., and et al. (2011) How many steps/day are enough? For adults. The international journal of behavioral nutrition and physical activity, 8(1), 79-79. 
Vallance, J. K., Courneya, K. S., Plotnikoff, R. C., Yasui, Y. and Mackey, J. R. (2007) Randomized controlled trial of the effects of print materials and step pedometers on physical activity and quality of life in breast cancer survivors. Journal of Clinical Oncology, 25(17), 2352-2359.

Van den Broucke, S. (2012). Theory-informed health promotion: seeing the bigger picture by looking at the details. Health Promotion International, 27(2), 143-147.

Van Den Broucke, S. (2014). Needs, norms and nudges: the place of behaviour change in health promotion. Health Promotion International, 29(4), 597-600

VicHealth (2012). VicHealth Indicators Survey 2011. Victorian Health Promotion Foundation, Melbourne, Australia.

Webb, T. and Sheeran, P. (2006). Does changing behavioural intentions engender behavior change? A meta-analysis of the experimental evidence. Psychological Bulletin, 132, 249-268.

World Health Organization (2011a). Fact sheet the top ten causes of death.

World Health Organization (2011b). Noncommunicable Diseases Country Profiles 2011.

Yates, T., Davies, M., Gorely, T., Bull, F. and Khunti, K. (2009) Effectiveness of a pragmatic education program designed to promote walking activity in individuals with impaired glucose tolerance: a randomized controlled trial. Diabetes Care, 32(8), 1404-1410. 
Table 1 Summary of literature review on walking promotion interventions

\begin{tabular}{|c|c|c|c|c|c|c|c|c|c|}
\hline \multirow[b]{2}{*}{ Author (year) } & \multirow[b]{2}{*}{ Design } & \multirow[b]{2}{*}{ 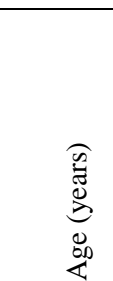 } & \multicolumn{4}{|l|}{ Intervention } & \multirow[b]{2}{*}{ Measures } & \multirow[b]{2}{*}{ Outcomes } & \multirow[b]{2}{*}{ 总 } \\
\hline & & & Theory & Construct & Component & 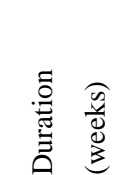 & & & \\
\hline $\begin{array}{l}\text { Arbour and } \\
\text { Martin Ginis } \\
\text { (2009) }\end{array}$ & $\begin{array}{l}\text { Single } \\
\text { blind RCT }\end{array}$ & 48.17 & $\begin{array}{l}\text { Implementation } \\
\text { intentions }\end{array}$ & & $\begin{array}{l}\text { Advice to achieve a goal of } 3500 \\
\text { additional pedometer steps on } 3 \\
\text { days/week and verbal } \\
\text { encouragement. }\end{array}$ & 6 & Pedometer & $\begin{array}{l}\text { Experimental group increase walking in first } 6 \text { weeks } \\
\text { compared to control group }\end{array}$ & + \\
\hline $\begin{array}{l}\text { Darker, French et } \\
\text { al. (2010) }\end{array}$ & $\begin{array}{l}\text { Waiting- } \\
\text { list control } \\
\text { RCT }\end{array}$ & $16-65$ & $\begin{array}{l}\text { Theory of Planned } \\
\text { Behaviour Extended }\end{array}$ & & $\begin{array}{l}\text { Motivational interviewing, goal } \\
\text { setting, action planning and } \\
\text { coping planning strategies }\end{array}$ & 5 & $\begin{array}{l}\text { Pedometer, } \\
\text { Neighbourhood } \\
\text { Physical Activity } \\
\text { (NPA) Questionnaire }\end{array}$ & $\begin{array}{l}\text { There was a significant difference in the number of } \\
\text { minutes walked and number of steps between the } \\
\text { intervention and control groups. The intervention } \\
\text { resulted in a large increase in the number of minutes } \\
\text { spent walking. Although level of increase was not } \\
\text { maintained. }\end{array}$ & $+\neq$ \\
\hline $\begin{array}{l}\text { De Cocker, De } \\
\text { Bourdeaudhuij et } \\
\text { al. (2008) }\end{array}$ & RCT & $18^{+}$ & $\begin{array}{l}\text { Social Cognitive } \\
\text { Theory }\end{array}$ & & $\begin{array}{l}\text { Information about the importance } \\
\text { of PA for health, the ' } 10000 \\
\text { steps/day' recommendation and } \\
20 \text { tips on how to increase PA } \\
\text { and advice to set walking goals }\end{array}$ & 3 & Pedometer, IPAQ & $\begin{array}{l}\text { A strong time effect was found, shows increases in } \\
\text { minutes/week walking, minutes/week moderate, and } \\
\text { minutes/week vigorous PA in both conditions. }\end{array}$ & + \\
\hline
\end{tabular}




\begin{tabular}{|c|c|c|c|c|c|c|c|c|c|}
\hline $\begin{array}{l}\text { De Greef, } \\
\text { Deforche et al. } \\
\text { (2011) }\end{array}$ & RCT & $62 \pm 9$ & & Support & $\begin{array}{l}\text { Motivational Interview, lifestyle } \\
\text { plan, telephone support and } \\
\text { pedometer }\end{array}$ & 24 & $\begin{array}{l}\text { Pedometer, } \\
\text { Accelerometer, IPAQ }\end{array}$ & $\begin{array}{l}\text { The intervention group increased their steps/day by } \\
2744 \text {, while the control group decreased by } 1256 \text {. The } \\
\text { effect remained after } 1 \text { year with an increase of } 1872 \\
\text { steps/day in the intervention group and a decrease of } \\
1275 \text { in the control group. The intervention group } \\
\text { increased their total PA by more than } 20 \text { min/day over } \\
\text { the short-term and more than } 10 \text { min/day over the } \\
\text { intermediate-term. At the same time the control group } \\
\text { decreased short-term (16 min/day) and intermediate- } \\
\text { term ( } 49 \text { min/day) total PA. The intervention group was } \\
12 \text { min/day less sedentary compared to their baseline } \\
\text { accelerometer levels while the control group had } \\
\text { increased sedentary behaviour by } 48 \text { min/day }\end{array}$ & + \\
\hline $\begin{array}{l}\text { Estabrooks, } \\
\text { Bradshaw et al. } \\
\text { (2008) }\end{array}$ & & $18^{+}$ & $\begin{array}{l}\text { Social Cognitive } \\
\text { Theory, Diffusion } \\
\text { Theory }\end{array}$ & $\begin{array}{l}\text { Empower } \\
\text { ment } \\
\text { Team } \\
\text { building }\end{array}$ & $\begin{array}{l}\text { Newsletter includes fun } \\
\text { messages, activities to increase } \\
\text { PA, weekly team mileage update } \\
\text { and flexibility to select team }\end{array}$ & 8 & $\begin{array}{l}\text { The Center for Disease } \\
\text { Control and Prevention } \\
\text { Behavioral Risk Factor } \\
\text { Surveillance Survey } \\
\text { questions }\end{array}$ & $\begin{array}{l}\text { Walk Kansas participants from the } 15 \text { randomly } \\
\text { selected counties increased minutes of moderate and } \\
\text { vigorous activity between baseline and } 8 \text { weeks. } \\
\text { However, the increase in moderate PA was significant } \\
\text { for inactive and insufficiently active individuals; it was } \\
\text { not significant for individuals who were already } \\
\text { meeting PA guidelines at baseline. }\end{array}$ & + \\
\hline
\end{tabular}




\begin{tabular}{|c|c|c|c|c|c|c|c|c|c|}
\hline $\begin{array}{l}\text { Faghri, Omokaro } \\
\text { et al. (2008) }\end{array}$ & Pre-post & $45+$ & $\begin{array}{l}\text { Transtheoretica } \\
\text { Model }\end{array}$ & $\begin{array}{l}\text { Motivation } \\
\text { Monitoring } \\
\text { and } \\
\text { feedback } \\
\text { Empower } \\
\text { ment } \\
\text { Team } \\
\text { building }\end{array}$ & $\begin{array}{l}\text { Pedometer, motivational } \\
\text { messages through email and } \\
\text { website and flexibility to choose } \\
\text { walking speed and team }\end{array}$ & 10 & $\begin{array}{l}\text { Health history } \\
\text { questionnaire }\end{array}$ & $\begin{array}{l}\text { There was a significant increase in the number of steps } \\
\text { per week for weeks 2, 3, 4, 5, } 6 \text { and } 8 \text { in comparison to } \\
\text { baseline. The average steps per person per week } \\
\text { reached } 23803 \pm 1720 \text { steps while the average steps per } \\
\text { day during the working hours at baseline were } 4185 \pm \\
174 \text { steps. }\end{array}$ & + \\
\hline $\begin{array}{l}\text { Furber, Butler et } \\
\text { al. (2010) }\end{array}$ & $\begin{array}{l}\text { Double } \\
\text { blinded } \\
\text { RCT }\end{array}$ & $\sim 65$ & $\begin{array}{l}\text { Social Cognitive } \\
\text { Theory }\end{array}$ & $\begin{array}{l}\text { Planning } \\
\text { and goal } \\
\text { setting } \\
\text { Support }\end{array}$ & $\begin{array}{l}\text { Pedometer, step calendar, } \\
\text { behavioural counselling, goal } \\
\text { setting session and telephone } \\
\text { support }\end{array}$ & 6 & $\begin{array}{l}\text { The Active Australia } \\
\text { Questionnaire, } \\
\text { Pedometer }\end{array}$ & $\begin{array}{l}\text { After } 6 \text { weeks, improvements in total physical activity } \\
\text { time, total physical activity sessions, walking time and } \\
\text { walking sessions in the intervention group were } \\
\text { significantly greater than the control. At } 6 \text { months, } \\
\text { physical activity improvements from baseline remained } \\
\text { significant within the intervention group with no } \\
\text { change in controls. }\end{array}$ & $+=$ \\
\hline $\begin{array}{l}\text { Hemmingsson, } \\
\text { Hellenius et al. } \\
\text { (2008) }\end{array}$ & & $44.4 \pm 13.1$ & $\begin{array}{l}\text { Transtheoretical } \\
\text { Model }\end{array}$ & Support & $\begin{array}{l}\text { Pedometer, walking promotion } \\
\text { booklet and group counselling } \\
\text { session. }\end{array}$ & 18 & Pedometer & $\begin{array}{l}\text { There was a linear increase by } 136 \text { steps/day in each } \\
\text { passing week. The added support (AS) group also } \\
\text { showed higher compliance with the } 10000 \text { steps/day } \\
\text { recommendation than the standard support (SS) group } \\
\text { ( } 14 \% \text { compared to } 0 \% \text { at baseline, and } 56 \% \text { compared } \\
\text { to } 0 \% \text { at } 18 \text { weeks). }\end{array}$ & + \\
\hline Keller and & Randomize & $45-70$ & & Motivation & Weekly walking session, athletic & 36 & Physical Activity & The number of minutes walked per week for "3-day & - \\
\hline
\end{tabular}




\begin{tabular}{|c|c|c|c|c|c|c|c|c|c|}
\hline Cantue (2008) & $\begin{array}{l}\mathrm{d} \text { and } \\
\text { repeated } \\
\text { measures }\end{array}$ & & & & $\begin{array}{l}\text { shoes and monthly educational } \\
\text { sessions }\end{array}$ & & $\begin{array}{l}\text { Recall and time walked } \\
\text { according to the PA } \\
\text { log, }\end{array}$ & $\begin{array}{l}\text { walking group” was } 63.72 \text { and that for "5-day walking } \\
\text { group” was } 129.15 \text { though the goal was for walking } 90 \\
\text { and } 150 \text { minutes per week, respectively. }\end{array}$ & \\
\hline $\begin{array}{l}\text { Kolt et al. (Kolt, } \\
\text { Schofield et al. } \\
\text { 2012) }\end{array}$ & RCT & $\geq 65$ & $\begin{array}{l}\text { Transtheoretical } \\
\text { Model }\end{array}$ & & $\begin{array}{l}\text { Primary care PA prescription, } \\
\text { telephone counselling }\end{array}$ & 12 & $\begin{array}{l}\text { Auckland Heart Study } \\
\text { Physical Activity } \\
\text { Questionnaire }\end{array}$ & $\begin{array}{l}\text { Leisure walking increased by } 49.6 \text { min/wk for } \\
\text { pedometer Green Prescription compared with } 28.1 \\
\text { min/wk for the standard Green Prescription. }\end{array}$ & + \\
\hline $\begin{array}{l}\text { Merom, Rissel et } \\
\text { al. (2007) }\end{array}$ & RCT & $30-65$ & $\begin{array}{l}\text { Social Cognitive } \\
\text { Theory }\end{array}$ & $\begin{array}{l}\text { Motivation } \\
\text { Monitoring } \\
\text { and } \\
\text { feedback } \\
\text { Education }\end{array}$ & $\begin{array}{l}\text { Pedometer, weekly diaries, self- } \\
\text { help booklet, and tips through } \\
\text { mail and telephone }\end{array}$ & 12 & $\begin{array}{l}\text { The Active Australia } \\
\text { Questionnaire (AAQ), } \\
\text { The College Alumni } \\
\text { Questionnaire (CAQ), }\end{array}$ & $\begin{array}{l}\text { There were significance within-group increases of all- } \\
\text { purpose walking (APW) and leisure-time walking } \\
\text { (LTW), but mean and median sessions and minutes } \\
\text { changes were greatest in the walking program with } \\
\text { pedometer (WPP) group. However, there were no } \\
\text { significant between-group differences in regular LTW, } \\
\text { except the WPP group increased significantly } \\
\text { participation in other sports/recreations. }\end{array}$ & \pm \\
\hline $\begin{array}{l}\text { Merom, Bauman } \\
\text { et al. (2009) }\end{array}$ & RCT & $30-65$ & $\begin{array}{l}\text { Social Cognitive } \\
\text { Theory }\end{array}$ & $\begin{array}{l}\text { Motivation } \\
\text { Monitoring } \\
\text { and } \\
\text { feedback }\end{array}$ & $\begin{array}{l}\text { Pedometer, weekly diaries, self- } \\
\text { help booklet, and tips through } \\
\text { mail and telephone }\end{array}$ & 12 & $\begin{array}{l}\text { Pedometer, The Active } \\
\text { Australia Questionnaire } \\
\text { (AAQ), The College } \\
\text { Alumni Questionnaire } \\
\text { (CAQ), }\end{array}$ & $\begin{array}{l}\text { Walking time at follow-up was lower if streetlights or } \\
\text { aesthetics were perceived to be “low” (-24\% and -22\% } \\
\text { respectively) compared with “high”. Even in “low” } \\
\text { aesthetic conditions, WPP participants were } \\
\text { significantly more likely than controls to increase total } \\
\text { walking time and to undertake regular walking, } \\
\text { whereas in aesthetically pleasing environments, the }\end{array}$ & \pm \\
\hline
\end{tabular}




\begin{tabular}{|c|c|c|c|c|c|c|c|c|c|}
\hline & & & & & & & & between-group differences were non-significant. & \\
\hline $\begin{array}{l}\text { Ornes and } \\
\text { Ransdell (2010) }\end{array}$ & $\begin{array}{l}\text { Pre-test, } \\
\text { post-test } \\
\text { quasi- } \\
\text { experiment } \\
\text { al }\end{array}$ & & & & & & Pedometer step counts & $\begin{array}{l}\text { Changes in self-efficacy as a result of the intervention } \\
\text { did not mediate walking behaviour. }\end{array}$ & - \\
\hline $\begin{array}{l}\text { Perry, Rosenfeld } \\
\text { et al. (2007) }\end{array}$ & $\begin{array}{l}\text { RCT, } \\
\text { single } \\
\text { blinded }\end{array}$ & $21-65$ & $\begin{array}{l}\text { Social Cognitive } \\
\text { Theory, } \\
\text { Transtheoretical } \\
\text { Model }\end{array}$ & & $\begin{array}{l}\text { MI, booster telephone call, } \\
\text { individualized and realistic goals, } \\
\text { progress monitoring, } \\
\text { individualized exercise } \\
\text { prescription, weekly group walk, } \\
\text { encouragement, positive } \\
\text { reinforcement, weekly } \\
\text { discussion, group T-shirt, } \\
\text { encouragement to telephone each } \\
\text { other, individualized and private } \\
\text { advice session and reinforcement } \\
\text { telephone call. }\end{array}$ & 12 & 12-minute walk test & $\begin{array}{l}\text { Women in the intervention group had a greater } \\
\text { improvement in cardiorespiratory fitness compared } \\
\text { with women in the comparison group }\end{array}$ & + \\
\hline $\begin{array}{l}\text { Prestwich, } \\
\text { Perugini et al. } \\
\text { (2010) }\end{array}$ & RCT & 23.44 & & $\begin{array}{l}\text { Motivation } \\
\text { Planning } \\
\text { and goal } \\
\text { setting }\end{array}$ & $\begin{array}{l}\text { Guideline for PA, benefits } \\
\text { through mobile text, } \\
\text { implementation plan, } \\
\text { implementation goal and text }\end{array}$ & 4 & $\begin{array}{l}\text { Self-Report Walking } \\
\text { and Exercise Tables } \\
\text { (SWET) }\end{array}$ & $\begin{array}{l}\text { Both intervention groups increased their brisk walking } \\
\text { compare to the control group. They increased the } \\
\text { number of days on which they met the physical activity } \\
\text { daily guidelines, through brisk and fast walking, }\end{array}$ & + \\
\hline
\end{tabular}




\begin{tabular}{|c|c|c|c|c|c|c|c|c|c|}
\hline & & & & $\begin{array}{l}\text { Education } \\
\text { Memory }\end{array}$ & reminder & & & $\begin{array}{l}\text { significantly more than that of control group. Forty-two } \\
\text { percent of the goal reminder group and } 45 \% \text { of plan } \\
\text { reminder group were benefited by at least an increase of } \\
2 \text { days per week compared to } 22 \% \text { of control group. }\end{array}$ & \\
\hline $\begin{array}{l}\text { Puig-Ribera, } \\
\text { McKenna et al. } \\
\text { (2008) }\end{array}$ & RCT & $31-58$ & & $\begin{array}{l}\text { Planning } \\
\text { and goal } \\
\text { setting } \\
\text { Education }\end{array}$ & $\begin{array}{l}\text { PA guideline, walking map, } \\
\text { pedometer, weekly goal, solution } \\
\text { to barriers and professional } \\
\text { support }\end{array}$ & 9 & Pedometer & $\begin{array}{l}\text { No significant group differences were found for } \\
\text { changes in work-day step counts. However, significant } \\
\text { increase in step counts (+659steps/day) were found } \\
\text { among 'Sedentary-Low active' participants when data } \\
\text { from the two intervention groups were pooled. In } \\
\text { contrast, there was a significant decrease (-637step/day) } \\
\text { in 'Active' participants and no change was found in } \\
\text { 'Moderately Active' participants. }\end{array}$ & \pm \\
\hline $\begin{array}{l}\text { Ryder, Faloon et } \\
\text { al. (2009) }\end{array}$ & & $18-65$ & $\begin{array}{l}\text { Social Ecological, } \\
\text { Social Cognitive } \\
\text { Theory }\end{array}$ & $\begin{array}{l}\text { Planning } \\
\text { and goal } \\
\text { setting } \\
\text { Education } \\
\text { Memory }\end{array}$ & $\begin{array}{l}\text { Pedometer, walking } \\
\text { recommendation, maps of local } \\
\text { trails, and advertisement through } \\
\text { poster, bookmarker, local } \\
\text { newspaper and radio }\end{array}$ & 24 & Pedometer & $\begin{array}{l}\text { 39.5\% of participants indicated that they walked more } \\
\text { since borrowing the pedometer, whereas } 60.5 \% \\
\text { reported walking about the same as before. None of the } \\
\text { respondents reported walking less. }\end{array}$ & \pm \\
\hline $\begin{array}{l}\text { Samuels, } \\
\text { Raedeke et al. } \\
\text { (2011) }\end{array}$ & RCT & $27-68$ & & Motivation & $\begin{array}{l}\text { Meeting principal investigator } \\
\text { weekly, pedometer, feedback and } \\
\text { accelerometer }\end{array}$ & 4 & $\begin{array}{l}\text { Pedometer, } \\
\text { accelerometer }\end{array}$ & $\begin{array}{l}\text { The } 10 \mathrm{~K} \text { and } 30 \text { min groups increased step counts } \\
\text { largely, whereas the bouts group changed a small over } \\
\text { the intervention period. }\end{array}$ & + \\
\hline
\end{tabular}




\begin{tabular}{|c|c|c|c|c|c|c|c|c|c|}
\hline $\begin{array}{l}\text { Speck, Hill et al. } \\
\text { (2010) }\end{array}$ & $\begin{array}{l}\text { Pre-post, } \\
\text { non- } \\
\text { controlled }\end{array}$ & & & $\begin{array}{l}\text { Motivation } \\
\text { Memory }\end{array}$ & $\begin{array}{l}\text { Pedometer, The } 10000 \text { Steps } \odot \\
\text { program materials, health } \\
\text { promotional activities (walk and } \\
\text { health fair, email/poster, raffle } \\
\text { draw for incentive (athletic } \\
\text { shocks, jackets, T-shirt and water } \\
\text { bottle), motivational success } \\
\text { stories, health snacks and prizes) }\end{array}$ & 21 & Pedometer & $\begin{array}{l}\text { The participants with medium and high activity levels } \\
\text { maintained their level of activity during intervention, } \\
\text { whereas those with low activity levels increased } 44 \% \text { of } \\
\text { average daily steps. However, participants who } \\
\text { reported < } 7499 \text { /day were less likely to continue during } \\
\text { the intervention. }\end{array}$ & + \\
\hline $\begin{array}{l}\text { Spence, Burgess } \\
\text { et al. (2009) }\end{array}$ & $\begin{array}{l}\text { Solomon } \\
\text { four-group }\end{array}$ & 30 & & & Pedometer and instruction & 1 & IPAQ, Pedometer & $\begin{array}{l}\text { Wearing pedometer increased self-reported walking. } \\
\text { The average number of steps taken per day was } 10293 .\end{array}$ & + \\
\hline $\begin{array}{l}\text { Strath, Swartz et } \\
\text { al. (2011) }\end{array}$ & $\begin{array}{l}\text { Randomize } \\
\text { d pilot trial }\end{array}$ & $63.8 \pm 6.0$ & $\begin{array}{l}\text { Transtheoretical } \\
\text { Model, Social } \\
\text { Cognitive Theory }\end{array}$ & $\begin{array}{l}\text { Motivation } \\
\text { Monitoring } \\
\text { and } \\
\text { feedback } \\
\text { Planning } \\
\text { and goal } \\
\text { setting } \\
\text { Education } \\
\text { Memory }\end{array}$ & $\begin{array}{l}\text { Educational PA literature } \\
\text { (educational materials on the } \\
\text { benefits of PA, how to make PA } \\
\text { as part of daily life) pedometer, } \\
\text { generic goal to increase PA up to } \\
10000 \text { steps/day, individualized } \\
\text { motivational literature (perceived } \\
\text { barriers to PA and effective } \\
\text { strategies to overcome it) and } \\
\text { telephone contact to discuss } \\
\text { barriers and strategies to }\end{array}$ & 12 & Pedometer & $\begin{array}{l}\text { Standard Education (SE) group did not differ in } \\
\text { accumulated steps/day following the intervention } \\
\text { compared with the Pedometer (P) +SE group. P + } \\
\text { Individualized Education (IE) group walked on average } \\
2159 \text { and } 1684 \text { steps/day more than the SE and P+SE } \\
\text { group respectively after intervention. P+IE+ Telephone } \\
\text { feedback (T) group walked on average } 2488 \text { and } 2013 \\
\text { steps/day more than SE and P+SE respectively after } \\
\text { intervention. Amount of walking of P+IE and P+IE+T } \\
\text { Group did not differ significantly. }\end{array}$ & \pm \\
\hline
\end{tabular}




\begin{tabular}{|c|c|c|c|c|c|c|c|c|c|}
\hline & & & & & $\begin{array}{l}\text { overcome it with trained research } \\
\text { assistant. }\end{array}$ & & & & \\
\hline $\begin{array}{l}\text { Sugden, } \\
\text { Sniehotta et al. } \\
\text { (2008) }\end{array}$ & RCT & $70-86$ & $\begin{array}{l}\text { Self-regulation } \\
\text { Theory }\end{array}$ & $\begin{array}{l}\text { Motivation } \\
\text { Monitoring } \\
\text { and } \\
\text { feedback } \\
\text { Planning } \\
\text { and goal } \\
\text { setting } \\
\text { Memory }\end{array}$ & $\begin{array}{l}\text { Motivational techniques, goal } \\
\text { setting techniques, barrier } \\
\text { identification and overcome } \\
\text { techniques, action plans, coping } \\
\text { plans, pedometer, daily activity } \\
\text { diary and telephone contact }\end{array}$ & & Accelerometer & $\begin{array}{l}\text { There was a greater increase in activity among the } 20 \% \\
\text { target pedometer group participants compared to the } \\
\text { other groups without gaining statistical significance. } \\
\text { The advice group met the target } 58 \% \text { of days compared } \\
\text { with } 61 \% \text { of days in the pedometer group. Among } \\
\text { pedometer groups, the } 10 \%, 15 \% \text { and } 20 \% \text { target } \\
\text { groups met } 55 \%, 57 \% \text { and } 74 \% \text { of their target level of } \\
\text { walking. }\end{array}$ & + \\
\hline $\begin{array}{l}\text { Tully, Cupples et } \\
\text { al. (2007) }\end{array}$ & RCT & $40-61$ & & $\begin{array}{l}\text { Motivation } \\
\text { Monitoring } \\
\text { and } \\
\text { feedback } \\
\text { Memory }\end{array}$ & $\begin{array}{l}\text { Pedometer and telephone } \\
\text { consultancy }\end{array}$ & $\begin{array}{l}122448 \\
7296\end{array}$ & Pedometer & $\begin{array}{l}\text { Change in walking was not reported. Systolic (5.0 } \\
\text { mmHg for 3-day group and } 6.0 \mathrm{mmHg} \text { for 5-day group) } \\
\text { and diastolic (3.4 } \mathrm{mmHg} \text { for 5-day group) blood } \\
\text { pressure, and waist ( } 2.6 \mathrm{~cm} \text { for } 3 \text {-day group and } 2.5 \mathrm{~cm} \\
\text { for 5-group) and hip ( } 2.4 \mathrm{~cm} \text { for 3-day group and } 2.2 \\
\mathrm{~cm} \text { for 5-day group) circumference were decreased } \\
\text { significantly due to walking. }\end{array}$ & + \\
\hline $\begin{array}{l}\text { Vallance, } \\
\text { Courneya et al. } \\
(2007)\end{array}$ & RCT & & & Education & $\begin{array}{l}\text { Standard recommendation for } \\
\text { PA, Exercise for Health materials } \\
\text { and pedometer }\end{array}$ & 12 & $\begin{array}{l}\text { Leisure Score Index } \\
\text { (LSI) of the Godin } \\
\text { Leisure-Time Exercise } \\
\text { Questionnaire, } \\
\text { Pedometer. }\end{array}$ & $\begin{array}{l}\text { PA increased by } 30 \text { minutes/week in the standard } \\
\text { recommendation (SR) group compared with 70, } 89 \text { and } \\
87 \text { minutes/week in the print material (PM), pedometer } \\
\text { (PED) and PM+PED groups respectively. For brisk } \\
\text { walking minutes/week, all three intervention groups }\end{array}$ & \pm \\
\hline
\end{tabular}




\begin{tabular}{|c|c|c|c|c|c|c|c|c|}
\hline & & & & & & & $\begin{array}{l}\text { reported significantly greater increases than the SR } \\
\text { group. Self-reported brisk walking minutes did not } \\
\text { change in the SR group compared with an increase of } \\
72,93 \text { and } 58 \text { minutes/week in the PM, PED and } \\
\text { PM+PED groups respectively. There were no } \\
\text { differences between any of the groups on objectively } \\
\text { measured steps per day. }\end{array}$ & \\
\hline $\begin{array}{l}\text { Yates, Davies et } \\
\text { al. (2009) }\end{array}$ & RCT & $\begin{array}{l}65 \\
\text { mean }\end{array}$ & $\begin{array}{l}\text { Monitoring } \\
\text { and } \\
\text { feedback } \\
\text { Planning } \\
\text { and goal } \\
\text { setting } \\
\text { Education }\end{array}$ & $\begin{array}{l}\text { Information leaflet (causes, } \\
\text { consequences, timeline of IGT, } \\
\text { benefits of PA to treat IGT, self- } \\
\text { efficacy beliefs, barriers to } \\
\text { walking and self-regulatory } \\
\text { strategies), pedometer, } \\
\text { encouragement to set steps/day } \\
\text { goal, group-based educational } \\
\text { program and encouragement to } \\
\text { set up time-based goals }\end{array}$ & 48 & Pedometer, IPAQ & $\begin{array}{l}\text { Objectively measured walking, self-reported walking } \\
\text { and overall MVPA increased significantly in } \\
\text { intervention groups compared with those in the control } \\
\text { group. }\end{array}$ & + \\
\hline
\end{tabular}

+ Effective, - Not effective, \pm Partially effective, $=$ Change maintained, $\neq$ Change not maintained, $\mathrm{x}$ walking change was not measured 
Table 2 Cross-tab and Fisher's exact test of effectiveness

\begin{tabular}{|c|c|c|c|c|c|c|}
\hline \multirow[t]{2}{*}{ Variable } & \multirow[t]{2}{*}{ Category } & \multirow[t]{2}{*}{ Theory usage } & \multicolumn{3}{|c|}{ Effectiveness } & \multirow[t]{2}{*}{ P-value } \\
\hline & & & $\begin{array}{l}\text { Not } \\
\text { effective } \\
\text { n (\%) }\end{array}$ & $\begin{array}{l}\text { Partial } \\
\text { effective } \\
\mathrm{n}(\%)\end{array}$ & $\begin{array}{l}\text { Fully effective } \\
\text { n (\%) }\end{array}$ & \\
\hline \multirow{2}{*}{ Theory used } & No & $11(44.0)$ & $2(18.2)$ & $2(18.2)$ & 7 (63.6) & \multirow{2}{*}{.388} \\
\hline & Yes & $14(56.0)$ & $0(0.0)$ & $4(28.6)$ & $10(71.4)$ & \\
\hline \multirow{2}{*}{ Multiple theory } & No & $10(71.4)$ & - & $2(20.0)$ & $8(80.0)$ & \multirow{2}{*}{.520} \\
\hline & Yes & $4(28.6)$ & - & $2(50.0)$ & $2(50.0)$ & \\
\hline \multirow[t]{9}{*}{ Name of theories } & No theory used & $11(44.0)$ & $2(18.2)$ & $2(18.2)$ & 7 (63.6) & \multirow[t]{9}{*}{.829} \\
\hline & Implementation Intention & $1(4.0)$ & $0(0.0)$ & $0(0.0)$ & $1(100.0)$ & \\
\hline & Social Cognitive Theory & $4(16.0)$ & $0(0.0)$ & $2(50.0)$ & $2(50.0)$ & \\
\hline & $\begin{array}{l}\text { Social Cognitive Theory \& Diffusion } \\
\text { Theory }\end{array}$ & $1(4.0)$ & $0(0.0)$ & $0(0.0)$ & $1(100.0)$ & \\
\hline & $\begin{array}{l}\text { Social Cognitive Theory \& Social } \\
\text { Ecological Model }\end{array}$ & $1(4.0)$ & $0(0.0)$ & $1(100.0)$ & $0(0.0)$ & \\
\hline & $\begin{array}{l}\text { Social Cognitive Theory \& } \\
\text { Transtheoretical Model }\end{array}$ & $2(8.0)$ & $0(0.0)$ & $1(50.0)$ & $1(50.0)$ & \\
\hline & Self-regulation Theory & $1(4.0)$ & $0(0.0)$ & $0(0.0)$ & $1(100.0)$ & \\
\hline & Theory of Planned Behaviour & $1(4.0)$ & $0(0.0)$ & $0(0.0)$ & $1(100.0)$ & \\
\hline & Transtheoretical Model & $3(12.0)$ & $0(0.0)$ & $0(0.0)$ & $3(100.0)$ & \\
\hline
\end{tabular}




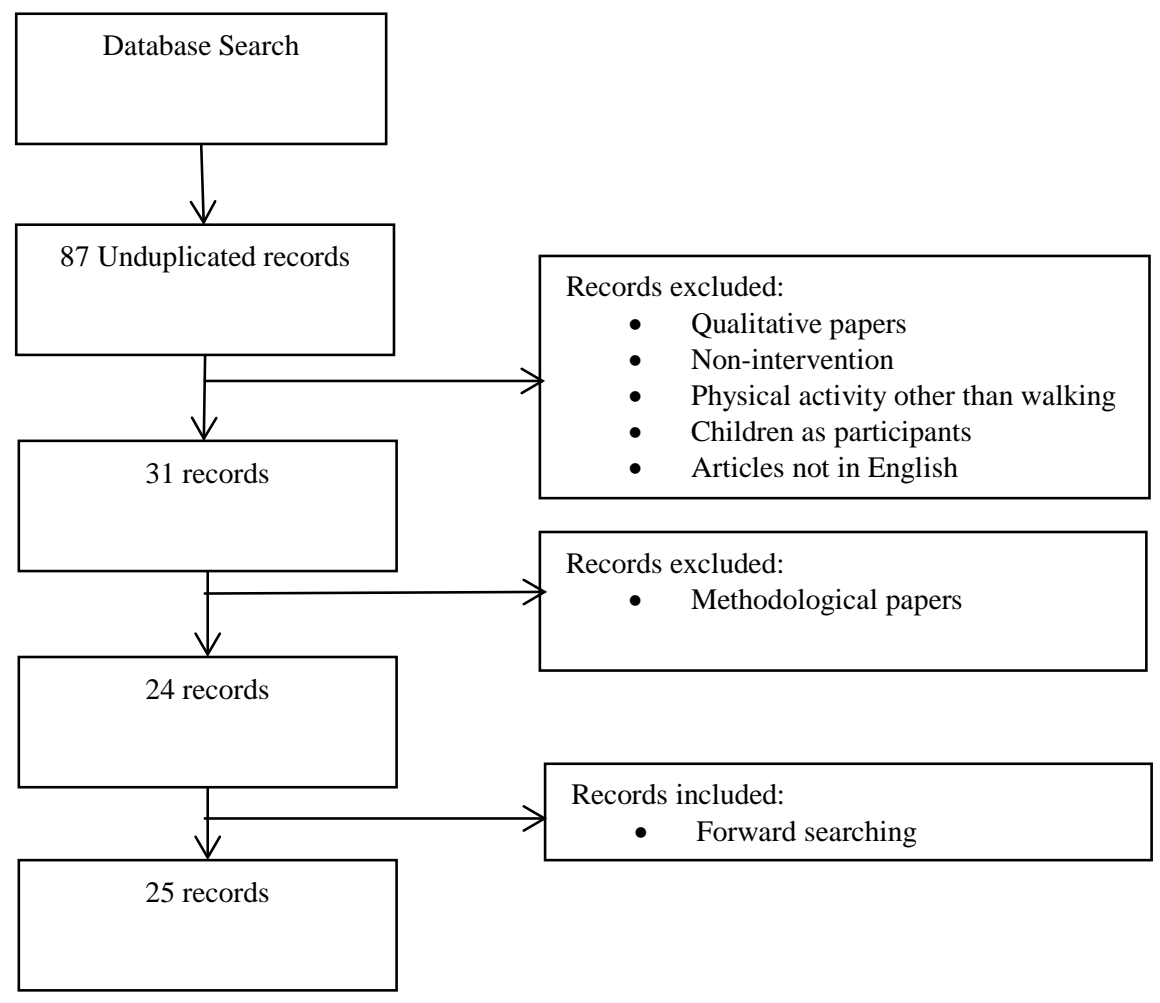

Figure 1 Flowchart of the search process 